\title{
Editorial
}

\section{DERMATOGLYPHICS A GOOD TOOL IN PREVENTIVE MEDICINE}

\author{
Mollik $\mathrm{MJH}^{1}$, Habib $\mathrm{MA}^{2}$
}

Dermatoglyphics refers to the branch of science in the study of the patterns of skin ridges (dermal ridges) present on the fingers, palm, toes and the soles of human ${ }^{1}$. Importance of finger print in modern world is not restricted to the field of forensic and criminal application only. Because of unveiling various unknown aspects of dermatoglyphics, the subject is developing its importance in every-day life. Now-adays in biology, anthropology, genetics and medicine, dermatoglyphics serves as a tool to describe, compare and contrast, and at times predict occurrences and risks for biomedical events studied by these major disciplinary areas. Fingerprints are an easily accessible, lifelong marker referable to early gestation. This is one of the best and most widely used method for personal identification.

The events for the establishment of the epidermal ridge pattern occur from the 6th to 19th week of prenatal development ${ }^{2}$. Fingerprints are not entirely a genetic characteristic. They are part of a 'phenotype' which means they are determined by the interaction of an individual's genes and the intrauterine environment (differing hormonal levels, nutrition, skin vascularization, blood pressure, position in the womb and the growth rate of the fingers at the end of the first trimester). Initial phase of epidermal glandular fold development is the most important phase of papillary ridge formation. Crucial events for the establishment of the epidermal ridge pattern take place from the 10th to the 16th week of pregnancy ${ }^{3}$. Pads (bumps) form on the foetal fingers and palms between 6 and 13 weeks of intra-uterine life. Where these bumps occur, how the foetus moves around inside the womb and how fast and big the foetus grows, all affect how the fingerprint patterns and ridges form and ensure the unique properties of fingerprints which are never duplicated. The details of persons' prints are unique to them and only them. Even identical twins do not have identical fingerprints. Each fingertip is related neurologically to a spinal-cord segment in a range that includes the sixth through the eighth cervical levels and might have influence on the developmental process ${ }^{4}$. The resulting fingertip ridge configuration (i.e., the fingerprint) is fixed permanently before the midpoint of pregnancy.
Fingerprints have been an object of scientific curiosity for a long time. In ancient China thumb prints were used on clay seals. In 1788 JC Mayer was the first to write out basic tenets of fingerprint analysis and theorized that fingerprints were unique. Dermatoglyphics as a scientific discipline began with the publication of thesis of Joannes Evangelista Purkinje, a Chech psychologist and biologist in 1823 and classic book, "Fingerprints" of Sir Francis Galton's in the year $1892^{5}$. In 1858, Sir William Herschel, noticed the use of thumbprints as a form of signature amongst illiterate Indians and clearly established the fact that fingerprints did not change their form over time and therefore could be used as a reliable form of personal identification. As an administrator he started using the finger print in practical field of work. Sir Edward Henry in the year 1893 published the book 'The Classification and Uses of Fingerprints" which established the modern era of finger print identification, which is now the basis for most of the other classification systems ${ }^{1}$.

During early part of twentieth century Dr Harold Cummins and Dr Charles Midlo utilized dermatoglyphics in medical research. They showed that the hand contained significant dermatoglyphic configurations that would assist the identification of mongolism in the new-born child. In course of time links between dermatoglyphics and diseases or congenital abnormalities have also been explored. The current state of medical dermatoglyphics is such that the diagnosis of some illnesses can now be done on the basis of dermatoglyphic analysis alone and currently, several dermatoglyphic researchers claim a very high degree of accuracy in their prognostic ability from the hand's features ${ }^{1,5}$.

Considerable progress has been made in the understanding of the associations between dermatoglyphics and various medical disorders, as a result of which dermatoglyphic analysis has been established as a useful diagnostic and research tool in medicine, providing important insights into the inheritance and embryologic development of many studied clinical disorders. Congenital anomalies like

1. Maj Gen Md Jahangir Hossain Mollik MBBS, MPH, MSLCP (USA), Commandant, AFMC; 2. Col Md Ahsan Habib MBBS, M Phil, Professor and Head, Department of Anatomy, AFMC. 
trisomy $21^{1}$ and $46 \mathrm{XY}$ female ${ }^{6}$ can have multiple effects on the phenotype, including the pattern of dermatoglyphics. Study showed that dermatoglyphics may be an important feature in psychiatric illness. Schizophrenia cases showed reductions in palmar $\mathrm{a}-\mathrm{b}$ ridge counts ${ }^{7}$, whereas radial loops were increased in bipolar mood disorder ${ }^{8}$. Pulliam et al proposed digital arch as a marker of the chronic intestinal pseudoobstruction ${ }^{9}$. Polovina et al found definite reflection in inderdigital area III and IV in cases of brachial plexus palsy ${ }^{10}$. The dermatoglyphic patterns may be utilized effectively to study the genetic basis of breast cancer and may also serve as a screening tool in the high-risk population ${ }^{11}$. Recent studies observed dermatoglyphics as diagnostic clue to various clinical conditions like acute lymphoblastic leukemia ${ }^{12}$, occupational allergic bronchitis ${ }^{13}$, locomotor disorder ${ }^{14}$, coeliac disease ${ }^{15}$, beta-thalassemia ${ }^{16}$ and many others.

The current issue of Journal of Armed Forces Medical College published a paper written by Manara et al. The author worked to find out the pattern of dermatoglyphics in normal healthy Bangladeshi to standardize pattern of finger print and compared that with the person suffering from myocardial infarction. Being an easy method, a series of study may be planned to identify pattern of dermatoglythics in person susceptibility to a particular disease and that may help the people to be careful before hand and design life accordingly.

\section{References}

1. Ramani P, Abhilash PR, Sherlin HJ, et al. Conventional Dermatoglyphics -Revived Concept : A Review. International Journal of Pharma and Bio Sciences 2011 July-September; 2(3): B446-B458.
2. Seidenberg-Kajabova H, Pospisilova V, Vranakova V, Varga I. An Original Histological Method for Studying the Volar Skin of the Fetal Hands and Feet. Biomed Pap Med Fac Univ Palacky Olomouc Czech Repub 2010 Sep; 154(3): 211-218.

3. Kückena M, Newell AC. Fingerprint Formation. Journal of Theoretical Biology 2005; 235: 71-83.

4. Kahn HS, Ravindranath R, Valdez R, Narayan KMV. Fingerprint Ridge-Count Difference between Adjacent Fingertips (dR45) Predicts Upper-Body Tissue Distribution: Evidence for Early Gestational Programming. American Journal of Epidemiology 2001; 153: 338-44.

5. Gyenis G. A short history and some results of the dermatoglyphic studies in Hungary. Acta Biologica Szegediensis 2000; 44(1-4):135-138. 6. Bosco JI, Rajangam S, Shankar J, Thomas IM. Dermatoglyphics in 46, XY females. J Indian Med Assoc. 2001 Aug;99(8):418-20.

7. Bramona E, Walshea M, McDonalda C, et al. Dermatoglyphics and Schizophrenia: A meta-analysis and investigation of the impact of obstetric complications upon a-b ridge count. Schizophrenia Research 2005; 75: 399- 404.

8. Chakraborty D, Mazumdar P, Than M, Singh R. Dermatoglyphic analysis in Malay subjects with bipolar mood disorder. Med J Malaysia. 2001 Jun;56(2):223-6.

9. Pulliam TJ, Schuster MM. Congenital markers for chronic intestinal pseudo-obstruction. Am J Gastroenterol 1995 Jun; 90(6): 922-6.

10. Polovina S, Milicic J, Cvjeticanin M, Proloscic TP. Qualitative dermatoglyphic traits in brachial plexus palsy. Coll Antropol 2007 Dec;31(4):1077-81.

11. Chintamani, Khandelwal R, Mittal A, et al. Qualitative and quantitative dermatoglyphic traits in patients with breast cancer: a prospective clinical study. BMC Cancer 2007 Mar 13; 7: 44.

12. Bukelo MJ, Kanchan T, Rau AT, Unnikrishnan B, Bukelo MF, Krishna VN. Palmar dermatoglyphics in children with acute lymphoblastic leukemia--a preliminary investigation. J Forensic Leg Med 2011 Apr;18(3):115-8.

13. Shemetova MV, Polzik EV, Kazantsev VS, Iakusheva MIu. Specific dermatoglyphic traits of patients with occupational allergic bronchitis. Genetika 2000 Jan;36(1):100-4.

14. Cvjeticanin M, Polovina A. Quantitative analysis of digitopalmar dermatoglyphics in male children with central nervous system lesion by quantification of clinical parameters of locomotor disorder. Acta Med Croatica. 1999;53(1):5-10.

15. Weizman Z, Vardi O, Binsztok M. Dermatoglyphic (fingerprint) patterns in coeliac disease. J Pediatr Gastroenterol Nutr. 1990 May;10(4):451-3.

16. Solhi H, Hashemieh M, Nejad ML, Vishteh HR, Nejad MR. Diagnostic value of fingerprint patterns: an explorative study on betathalassemia diagnosis. Bangladesh Med Res Counc Bull 2010 Apr;36(1):27-31 